\title{
Understanding cause/effect relationships in stock- ing rate change over time
}

\author{
R. C. ROWAN, LARRY D. WHITE, AND J. RICHARD CONNER
}

\begin{abstract}
Authors are research associate, Department of Rangeland Ecology and Management, College Station 77843-2126; professor and Extension Range Specialist, Texas Agricultural Extension Service, College Station 77843-2126; and professor, Department of Agricultural Economics, Texas A\&M University, College Station 77843-2124. At the time of the research, Rowan was Tom Slick Senior Graduate Fellow, Department of Rangeland Ecology and Management, Texas A\&M University.
\end{abstract}

\section{Abstract}

Decisions made by Texas ranchers over a 10 year period (19801990) concerning stocking rate levels were dominated by perceptions about weather. A regression model explained $64 \%$ of the variability in stocking rate change over time, with the rainfall/drought variable explaining the majority of variability. As ranchers' perception of a positive rainfall effect increased, so did stocking rates, and vice versa. Although the presence or absence of rainfall cannot be managed per se, proactive stocking decisions should include a strategy for adjusting stocking levels in response to changing environmental conditions.

Other factors with significant $(\alpha=0.05)$, albeit trivial, path coefficients on stocking rate change were age, grazing rights (owned vs. leased), traditional stocking rate factors, traditional grazing program factors, and weed/brush information factors. Older ranchers ( $>65$ years) and ranchers who leased all of their rangeland tended to decrease stocking rates over time. Rangeland operators indicated they considered "improved livestock performance" as the most important benefit from initiating a grazing program. Evidence also suggested that ranchers who rely on their neighbors for advice about weed/brush decisions are not benefitting from the latest technology information. Adoption of economic factors (cost/benefits) for selection of weed/brush technology did not have a significant impact on stocking rates over the $\mathbf{1 0}$ year period.

Key words: principal component, path coefficient analysis, regression, ranch decision-making, direct and indirect effects

It may not be news to range professionals that ranchers around the country often think differently! But the discussion doesn't end there. An enlightening thing about sociological research is not so much that people think differently about values and beliefs, but that they frequently think similarly. Similarities among human populations point to groups or clusters of people who embrace similar beliefs or ideas which become springboards for causing change as these groups exert influence. There is no reason to think that the ranching community behaves any differently.

Social science is unlike the "hard" sciences in that the subjects being studied cannot be observed under laboratory conditions. Sociologists do not control all of the conditions under which human populations are observed. Similarities in people are observable and, to some extent, measurable when asked to respond to specific questions,

\footnotetext{
Research was funded by the USDA Soll Conservation Service and the Texas Agricultural Extension Service. Authors wish to thank Mr. Paul Pope, Extension Computer Specialist, for his contributions to data analysis.

Manuscript accepted 22 Feb. 1994.
}

such as the statewide survey of Texas ranchers (Hanselka et al. 1990).

Techniques such as discriminant analysis have been developed to compare and contrast human responses. Path analysis has been used in biological research to segregate treatment cause/effects (Singh and Chowdhury 1983, Kang et al. 1983, van Bruggen and Arneson 1986, Bowers et al. 1990, Mebrahtu et al. 1991). However, the procedure has been infrequently used in rangeland research. White (1968) was one of the earliest rangeland researchers to use the technique to quantify the factors affecting susceptibility of creosotebush, Larrea tridentata (D.C.) Cov., to burning. Path coefficient regression analysis in biological systems is characterized by high $R^{2}$ values reflecting the control of unrelated variables. Inclusion of sociological data in path analysis may reduce explanatory power of regression models because of extraneous influences, but the interpretations on human behavior are no less important.

Modeling rancher decision-making is a process of generating a priori assumptions, formulating a causal scheme among variables $(\mathrm{Li}$ 1975), calculating path effects, and proposing plausible interpretations about significant pathways. Because human ecological systems are complex interactions between value-based decision-making and the surrounding environment, causal schemes should include biological as well as sociological variables and the model structure should be such that significant effects are interpretable (Li 1975). The constraints in "real world" situations continue to be the complex and individualistic factors that both precede and characterize a rancher's decision process. Identification and measurement of relevant characteristics in conjunction with discovery of cause/effect pathways should provide better understanding of rancher's decision-making and the impacts on rangeland resources. The main objective of this study was to determine significant $(P \leq 0.05)$ direct and indirect effects of rancher attributes, ranch characteristics, rainfall effects, percent of total income from various sources, and decision variables on stocking rate change over a 10 year period for all Texas rangeland operators.

\section{Methods}

Procedures like path coefficient regression analysis can be used to trace the cause and effect relationships between quantifiable characteristics and the changes they effect. More precisely, path analysis is the decomposition of observed correlation between variables in a hypothesized causal scheme. Correlation coefficients are by definition standardized covariances. Since covariances can be subdivided into various parts, correlation coefficients may also be subdivided to see the cause/effect structure among variables.

A path model was constructed from variables representing personal rancher attributes, ranch characteristics, rainfall effects, on and offranch income levels as a percent of total income, and principal component decision variables to determine their effects on animal stock- 


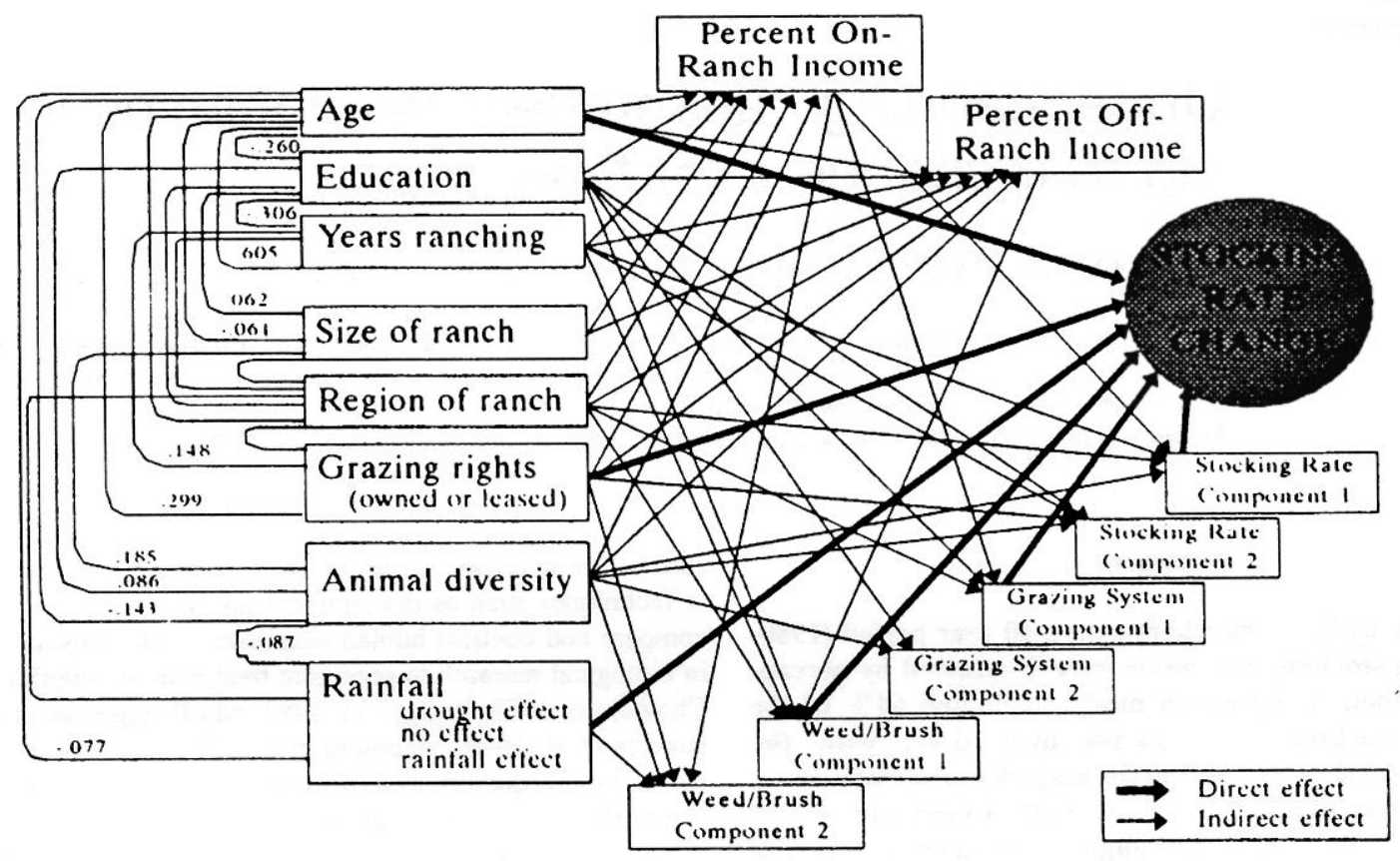

Fig. 1. Significant pathways from combined regression models of personal, ranch and rainfall characteristics; income sources; and decision variables influencing stocking rate change over time.

ing rate change over time (see Fig. 1 for variable scheme). The dependent variable was measured as decreased stocking rate, no change in stocking rate, or increased stocking rate over the 10 year period from 1980-1990.

Variables for age of the rancher, years of ranching experience and size of the ranch were measured as interval variables. The variable for level of education was given numerical scores for regression analysis ${ }^{1}$. Grazing rights were scored from 1 to 3 . The higher the number the closer to full ownership of the ranch'.

Ranchers who owned land but leased it to someone else were eliminated from this portion of the study because this category did not fit the ordering towards full ownership/management. Animal diversity was also scored with larger numbers representing more animal enterprises operated on the ranch. The rainfall variable was a composite of answers to specific portions of 2 questions. Specifically, ranchers were given the opportunity to register their perception of either "drought" or "rainfall" as factors affecting either increased or decreased stocking. If respondents did not check either response, their response was coded as "no effect."

Regional ranch location was entered into regression analysis as dummy variables after Kennedy (1989:180). The procedures for dummy variables puts the effect of the omitted variable, or base variable, into the intercept term. Each dummy variable is then compared against this base variable. Regression coefficients for dummy variables represent their departure, either positively or negatively, from the base variable. The base variable for location was specified as the High Plains region.

Independent variables measuring income sources were defined as follows: on-ranch income was the combined percent of total family

'Levels of formal education were recoded as numerical scores: $1=$ no formal education, 2 = grade school education, $3=$ high school education, $4=$ some college, $5=4$-year college degree, and $6=$ advanced degree.

${ }^{2}$ Grazing rights were coded as follows: 1 = all grazing land is leased from others, $2=$ ranch is a combination of leased and deeded land, and $3=$ all ranch land is owned and operated by same individual. income from livestock, wildlife, and hay/seed production; and offranch income was the combined percent of total family income from off-ranch investments and off-ranch employment.

The 6 decision variables representing the three categories ( 2 principal components for each category): stocking rate, grazing programs, and weed/brush techniques were derived from the scoring coefficients of the principal component analysis (Rowan et al. 1994). The number of principal components selected for each category was based on eigenvalues greater than 1.0.

The direct effects, and subsequently the indirect effects of variables on stocking rate change, were derived from standardized coefficients from the following regressions: (1) regressing age, education, years ranching, size of ranch, region of ranch, grazing rights, animal diversity and rainfall effects, individually, on on-ranch and off-ranch income percentages, (2) regressing age, education, years ranching, size of ranch, region of ranch, grazing rights, animal diversity, rainfall effects, on-ranch and off-ranch income percentages, individually, on each of the decision variables, and (3) regressing all variables on past stocking rate changes. Values for direct effects were simply the standardized path coefficient between the independent variable and the overall dependent variable in the model (i.e., in this model it was stocking rate change). Indirect effects were calculated as the product of a path coefficient and a correlation coefficient $\left(r_{i j} P_{j k}\right)$. For example, the indirect effect of Age $_{i}$ on Stocking Rate Change ${ }_{k}$ through Stocking Rate Component $1_{j}$ would be traced back along significant pathways from Stocking Rate Change through Age, Percent OnRanch Income, and Stocking Rate Component $1\left(r_{i j}\right)$ and then from Stocking Rate Component1 to Stocking Rate Change $\left(\mathrm{P}_{\mathrm{jk}}\right)$ to complete the loop.

Standardization of regression coefficients enabled comparison across variables. The coefficients could then be interpreted as that change in the standard deviation of the dependent variable resulting from a 1 unit change in the standard deviation of the causation variable. Regression coefficients which tested significantly different from zero were retained until all regressions were completed. 
Lastly, variables for age, grazing rights, and rainfall were segregated into categories to test if partial variable effects had significant but opposing coefficient signs. Each category of the three variables was coded into dichotomous dummy variables and tested individually in the regression models. The dummy variable for age was coded as presence or absence in the following groups: $\leq 35$ years, $36-65$ years, and $>65$ years. Likewise, grazing rights was coded $(0,1)$ for categories: leased all land, owned and leased land, and owned and operated all land. Dummy variable for rainfall represented a rancher's perception of a drought effect, no effect, or an increased rainfall effect.

\section{Results and Discussion}

Twenty-two variables, including the dependent variable, were involved in the regression analysis. Bivariate correlation coefficients of the exogenous variables were examined to identify statistically significant associations. For example, size of the ranch was positively correlated (.185) and age was negatively correlated (-.143) with animal diversity (see Fig. 1). Thus, ranchers operating larger ranches tended to have more animal enterprises on the ranch, while older ranchers tended to have fewer animal enterprises.

Age of the rancher and the number of years of ranching experience were highly correlated (.605). Furthermore, age of ranchers and years of ranching experience were each negatively correlated with education, indicating older and more experienced ranchers had lower levels of formal education. The positive correlation (.299) between age of the rancher and tendency toward full ownership of the ranch was not unexpected. In addition, rancher age was inversely correlated, albeit trivial, with the rainfall variable, which meant that older ranchers were more likely to perceive a drought effect changing stocking rate levels.

\section{Direct Effects on Percent On-Ranch Income}

Only the direct effects will be reported for each model because the indirect effects were generally well below 0.018 and considered trivial. The model regressing personal attributes, ranch characteristics, and rainfall effects explained $22 \%$ of the variation in percent of total family income from on-ranch sources (Table 1). The path coefficient between age and percent on-ranch income was negative $(-.200)$. Repeating the regression with age segregated into 3 dummy categories ( $\leq 35$ years, 36-65 years, and $>65$ years) showed that the younger group obtained a larger $(.108)$ and the older group a smaller portion $(-.065)$ of their total family income from on-ranch sources.

Table 1. Tests of significant path coefficients for the regression of personal attributes, ranch characteristics, and rainfall effects on percent of total income from on-ranch sources.

\begin{tabular}{lccc}
\hline Source & $\begin{array}{c}\text { Regression } \\
\text { Coefficients }\end{array}$ & $\begin{array}{c}\text { Path } \\
\text { Coefficients }\end{array}$ & $\begin{array}{c}\mathrm{t} \\
\text { Value }\end{array}$ \\
\hline Intercept & 51.4455 & 0.0000 & $9.434^{* * *}$ \\
Personal Attributes & & & \\
Years ranching & 0.6723 & 0.3317 & $9.848^{* * *}$ \\
Age & -0.4452 & -0.1998 & $-5.794^{* * *}$ \\
Education & -2.6927 & -0.1039 & $-3.775^{* * *}$ \\
Ranch Characteristics & & & \\
Size of ranch & 0.0002 & 0.1395 & $5.194^{* * *}$ \\
Blacklands region & -8.0690 & -0.1195 & $-4.065^{* * *}$ \\
Coastal Prairie region & -9.8550 & -0.0889 & $-3.208^{* *}$ \\
Rio Grande Plains region & -7.5336 & -0.0935 & $-3.369^{*}$ \\
Grazing rights & -2.1160 & -0.0585 & $-2.093^{* * *}$ \\
Animal diversity & 3.4076 & 0.1663 & $5.914^{* * *}$ \\
n=1173 & $\mathrm{R}^{2}=0.2156$ & Adj. $\mathbf{R}^{2}=0.2095$ & \\
Non-significant variables: Rolling Plains region, Trans Pecos region, Edwards \\
Plateau region, Rainfall effects & & \multicolumn{3}{l}{} \\
\hline
\end{tabular}

'Path coefficients are standardized regression coefficients.
The path coefficient between number of years of ranching experience and percent on-ranch income was 0.332 . Each standard deviation change in the number of years ranching caused a 0.332 change in standard deviation of percent of total family income from on-ranch sources. Although there was a positive correlation between age and ranching exerpence, ranchers with more years of experience had larger portions of their incomes derived from on-ranch sources, but this was not necessarily true for older ranchers.

The path coefficient for the grazing rights variable was also negative. Although the coefficient was small $(-.058)$, the implication was that as ranchers move toward full ownership they derive a significantly smaller portion of total family income from on-ranch sources, thus they were ostensibly more reliant on other income sources. Partitioning of grazing rights showed that on-ranch income was more important to ranchers who leased all of their land from others (.052) than ranchers who owned all of their land (-.051).

\section{Direct Effects on Percent Off-Ranch Income}

Regressing personal attributes, ranch characteristics, and rainfall effects on percent of total family income from off-ranch sources produced a model $(P<.0001)$ explaining $24 \%$ of the variation in off-ranch income. T-tests revealed significant relationships (Table 2) between all exogenous variables and percent off-ranch income except the rainfall variable $(P=.111)$. Percent off-ranch income significantly increased with age (.095), and segregation of age confirmed that the younger age group derived a significantly smaller portion of their total family income from off-ranch income (-.081) than did other age groups. The path coefficient for the "over 65 " age category was also negative, but not significant. Presumably, the proportion of off-ranch employment income decreased for this group while off-ranch investments increased. (Rowan and White 1994).

Path coefficients for size of ranch, animal diversity and years ranching were negative, hence off-ranch income was less important on larger ranches, on ranches with more animal enterprises, and for ranchers with more years of ranch experience.

\section{Direct Effects on Traditional Stocking Rate Factors}

Personal attributes, ranch characteristics, rainfall effects, and income sources regressed on the importance of traditional stocking rate factors (i.e., forage and livestock considerations, weather and past experience) produced a model $(P<.0001)$ explaining $6 \%$ of the variation in traditional stocking rate factors. Ranchers who had been ranching longer, who utilized multiple animal enterprises, and who obtained higher percentages of on-ranch income tended to rate the traditional stocking rate factors more importantly (on the Likert scale of importance).

Partitioning age effects on the importance of traditional stocking rate factors showed that ranchers in the 36-65 age category considered these factors significantly more important to them. Evidently, ranchers $<36$ and $>65$ years had little affinity for the traditional stocking rate factors and their influence rendered the overall age effect nonsignificant.

\section{Direct Effects on Nontraditional Stocking Rate Factors}

Personal attributes, ranch characteristics, rainfall effects, and income sources regressed against the importance of nontraditional stocking rate factors (i.e., wildlife considerations and other people's advice) produced a significant model explaining $8 \%$ of the variability in the dependent variable.

Ranchers with more animal enterprises (.249) and who were closer to having full ownership of their ranches (.155) considered other people's advice and wildlife considerations to be more important. Segregation of the grazing rights variable indicated that the signifi- 
Table. 2. Tests of significant path coefficients for the regression of personal attributes, ranch characteristics, and rainfall effects on percent of total income from off-ranch sources.

\begin{tabular}{lccc}
\hline Source & $\begin{array}{c}\text { Regression } \\
\text { Coefficients }\end{array}$ & $\begin{array}{c}\text { Path } \\
\text { Coefficients }\end{array}$ & $\begin{array}{c}\mathbf{t} \\
\text { Value }\end{array}$ \\
\hline $\begin{array}{l}\text { Intercept } \\
\text { Personal Attributes }\end{array}$ & 5.9967 & 0.0000 & 0.828 \\
\hline Years ranching & & & \\
Age & -0.6464 & -0.2573 & $-7.753^{* * *}$ \\
$\quad$ Education & 0.2620 & 0.0948 & $2.775^{* *}$ \\
Ranch Characteristics & 5.4782 & 0.1707 & $6.289^{* * *}$ \\
$\quad$ Size of ranch & & & \\
Rolling Plains region & 12.0681 & -0.0856 & $-3.144^{* *}$ \\
Trans Pecos region & 19.7179 & 0.1167 & $2.767^{* * *}$ \\
Edwards Plateau region & 23.7578 & 0.1701 & $4.263^{* * *}$ \\
Blacklands/Cross Timbers & & 0.2562 & $5.530^{* * *}$ \\
region & 31.4074 & 0.3751 & $7.626^{* * *}$ \\
Coastal Prairie region & 27.5264 & 0.2003 & $5.544^{* * *}$ \\
Rio Grande Plains region & 26.7096 & 0.2675 & $6.135^{* * *}$ \\
Grazing rights & 3.4855 & 0.0778 & $2.789^{* *}$ \\
Animal diversity & -5.4129 & -0.2132 & $-7.427^{* * *}$ \\
$\mathrm{n}=1173$ & $\mathrm{R}^{2}=0.2417$ & Adj. $\mathbf{R}^{2}=0.2339$ \\
$\quad$ Non-significant variable: Rainfall effects & & \\
\hline
\end{tabular}

Path coefficients are standardized regression coefficients.

*.***** Indicates significant differences at the $0.05,0.01$ and 0.001 levels, respectively.

ership (.168). Ranchers with a leased component in their operations (owned \& leased or leased all land) felt the nontraditional stocking rate factors were less important to them. Lastly, those ranchers with more years of ranching experience (-.084) and more education (-.081) gave less credence to other people's advice and wildlife considerations.

\section{Direct Effects on Traditional Grazing Program Factors}

Regressing personal attributes, ranch characteristics, rainfall effects, and income sources on the importance of traditional grazing program factors produced a model $(P<.0009)$ explaining $2 \%$ of the variability. Apparently, there was considerable variability in the grazing program decisions of ranchers. Ranchers who owned and leased land (more likely full-time ranchers) rated the traditional grazing factors (i.e., improved livestock performance, improved amount or kind of forage, improved grazing distribution, etc.) to be significantly more important to them than did full-ownership or tenant ranchers.

\section{Direct Effects on Nontraditional Grazing Program Factors}

The model $(P<.0001)$ which regressed personal attributes, ranch characteristics, rainfall effects, and income sources on the importance of nontraditional grazing program factors explained $7 \%$ of the variability in the dependent variable. Ranchers with more animal enterprises tended to consider the nontraditional grazing factors (i.e., obtain other people's approval, improved wildlife habitat, and reduced labor requirements) to be more important to them. Those ranchers who had higher levels of formal education considered the nontraditional grazing program factors to be less important. Evidently, better educated ranchers discounted these 3 variables in their operations.

\section{Direct Effects on Weed/Brush Technique Information Factors}

Regressing personal attributes, ranch characteristics, rainfall effects, and income sources on the importance of information factors upon weed/brush treatment techniques produced a significant model explaining $4 \%$ of the variability in the dependent variable. Ranchers in the Rolling Plains and Rio Grande Plains rated the weed/brush information factors (i.e., advice from neighbors, fear of treatment method, advice from agencies, etc.) higher than ranchers in other regions. However, ranchers with more ranching experience, with more formal education, and with larger portions of their incomes from offranch sources considered the information factors to be less important.

Ranchers between the ages of 35 and 65 were more likely to embrace the sources of information for weed/brush treatment techniques than other age categories $(P=.086)$. Older ranchers ( $>65$ years) did not perceive weed/brush information sources as important to them as did other ages $(P=.067)$.

\section{Direct Effects on Weed/Brush Economic Factors}

The model regressing personal attributes, ranch characteristics, rainfall effects, and income sources on weed/brush economic factors (i.e., plant attributes, projected economic returns, cost of treatment, etc.) explained $6 \%$ of variability in the dependent variable. Percent of total income from on-ranch sources had the largest impact on weed/brush economic factors (.177). Ranchers who derived higher percentages of their total family income from on-ranch sources tended to rate the weed/brush economic factors more importantly. In addition, ranchers who had more animal enterprises and those who were closer to full ownership of their ranches tended to consider the weed/brush economic factors to be more important.

The second largest path coefficient was the rainfall variable $(-.127)$. The negative coefficient meant that as conditions move toward a positive rainfall effect, ranchers considered the weed/brush economic factors to be less important. Individual dummy effects of "drought" and "no effect" had significant and opposite coefficient signs. Ranchers who perceived a drought effect over the previous 10 year period considered economic factors of weed/brush decision-making to be more important. Apparently, the importance of economic considerations begins to wane when the effect of rainfall is either neutral or positive.

\section{Direct Effects on Stocking Rate Change Over Time}

The regression of personal attributes, ranch characteristics, rainfall effects, and all 6 decision variables on stocking rate change produced a significant model explaining $64 \%$ of the variability in stocking rate change (Table 3). A strong, positive relationship (.782) exists between perceived rainfall effects and stocking rate change. Conversely, partitioning the effects of the rainfall variable revealed that a perceived drought effect by ranchers strongly influenced a decline in stocking rates over time $(-.775)$.

Five variables had small direct effects on stocking rate change. Rancher age had a negative effect $(-.054)$ on stocking rate change while grazing rights had a positive effect $(.046)$. Ranchers over 65

Table 3. Tests of significant path coefficients for the regression of personal attributes, ranch characteristics, rainfall effects, income sources, and decision variables on stocking rate change over time.

\begin{tabular}{|c|c|c|c|}
\hline Source & $\begin{array}{l}\text { Regression } \\
\text { Coefficients }\end{array}$ & $\begin{array}{c}\text { Path } \\
\text { Coefficients }\end{array}$ & $\begin{array}{c}t \\
\text { Value }\end{array}$ \\
\hline Intercept & -0.7218 & 0.0000 & $-3.631 * * *$ \\
\hline \multicolumn{4}{|l|}{ Personal Attributes } \\
\hline Age & -0.0035 & -0.0544 & $-2.385^{*}$ \\
\hline \multicolumn{4}{|l|}{ Ranch Characteristics } \\
\hline Grazing rights & 0.0448 & 0.0458 & $2.024^{*}$ \\
\hline Rainfall Effects & 1.1770 & 0.7820 & $35.783^{* * *}$ \\
\hline \multicolumn{4}{|l|}{ Decision Variables } \\
\hline Traditional stocking factors & 0.0742 & 0.0578 & $2.506^{*}$ \\
\hline Traditional grazing factors & 0.0864 & 0.0730 & $3.152 * *$ \\
\hline \multicolumn{2}{|c|}{ Weed/Brush information factors- 0.0454} & -0.0593 & $-2.714 * *$ \\
\hline $\mathrm{n}=780$ & $R^{2}=0.6338$ & Adj. & $=0.6340$ \\
\hline
\end{tabular}

Non-significant variables: Education, Years ranching, Size of ranch, Rolling Plains region, Trans Pecos region, Edwards Plateau region, Blacklands/Cross Timbers region, Coastal Prairie region, Rio Grande Plains region, Animal diversity, Percent On-ranch income, Percent Off-ranch income

'Path coefficients are standardized regression coefficients.
$*, * *, * * *$ Indicates significant differences at the $0.05,0.01$ and 0.001 levels, respectively. 
years of age tended to reduce stocking rates $(P=.082)$ more than did other ages of ranchers. Likewise, ranchers who leased all of their land from someone else tended to reduce stocking rates over time $(P=.006)$ more than did other tenure types.

Path coefficients for each of the first principal components between stocking rate factors (.058), grazing programs (.073), and weed/brush techniques (-.059) and stocking rate change were significant.

Although pathways connected personal attributes and ranch characteristics to both income sources, to simplify the model (Fig. 1) only variables with significant direct paths to the response variable, stocking rate change, were retained in the final model (Fig. 2). Examination of the decision variables showed that the second component of each category did not significantly impact stocking rate change, thus they were removed from the model.

\section{Conclusions}

Increasing stocking rates over time appears to be motivated by a rancher's perception of increased rainfall. Alternately, ranchers react to drought by decreasing stocking levels. Neither of these management practices are good measures of the state of the land. "Trends in animal production are obscured by large peaks and troughs caused by the rainfall. As an ecosystem degrades, domestic stock show an ability to maintain production by switching to less palatable plants or plant communities, but then may crash to a lower level of production, perhaps when drought intervenes to apply the coup de grace to the already stressed perennial pasture plants" (Harrington et al. 1984). This is the essence of crisis management. "Rainfall more than any other factor influences the productivity of range pastures...Any rancher then has to be able to predict the effects of a poor rainfall year, and has to be able to modify his management strategies to fit in with a sudden downturn in rainfall received..This means that the rancher has to understand the rainfall pattern in his environment" (Wilcox 1982:19).
Although the presence or absence of rainfall cannot be managed per se, proactive stocking rate decisions should include a strategy for adjusting stocking levels in response to changing environmental conditions (Wilson and Macleod 1991). Survey results indicated $45 \%$ of ranchers do not make seasonal adjustments to livestock numbers. If reductions in livestock numbers were reported by ranchers, most reductions were "blamed" on drought. Wilson et al. (1984) noted that if a conservative stocking rate strategy were employed, a $30-50 \%$ stock reduction would be required during short-term drought and $75 \%$ or more during long-term droughts. However, less than $20 \%$ of ranchers use a quantifiable technique (photopoints and/or exclosures) to monitor their grazing management or stocking rate decisions over the short or long term (Hanselka 1990). Ranchers should utilize knowledge about precipitation patterns and probabilities, plant growth cycles, forage inventory procedures to balance forage supply/demand, and flexible livestock marketing techniques to achieve their goals.

Path analysis showed that age and ownership have statistically significant, albeit small, effects on stocking rate change. Age is a diffusion variable which has been shown to be a statistically significant predictor of adoption (Ladewig 1977, Thomas et al. 1990). Older Texas ranchers reported a lower stocking rate level over time. It is hard to determine if this is a purposeful reduction with increased financial security, a more conservative approach (i.e., less stress and less risk) due to past "bad" experiences during drought situations, or a reaction to declining efficiency of the rancher over the family-firm cycle.

Because $75 \%$ of rangeland leases are short-term (five years or less) and payment is made on a per-acre basis (Hanselka 1990), stocking rates have traditionally been excessive, thus promoting range deterioration. This scenario is supported by results showing ranchers who lease all of their land tend to decrease stocking rates over time. Lease contracts that are long-term, charge on a per animal unit basis, and in-

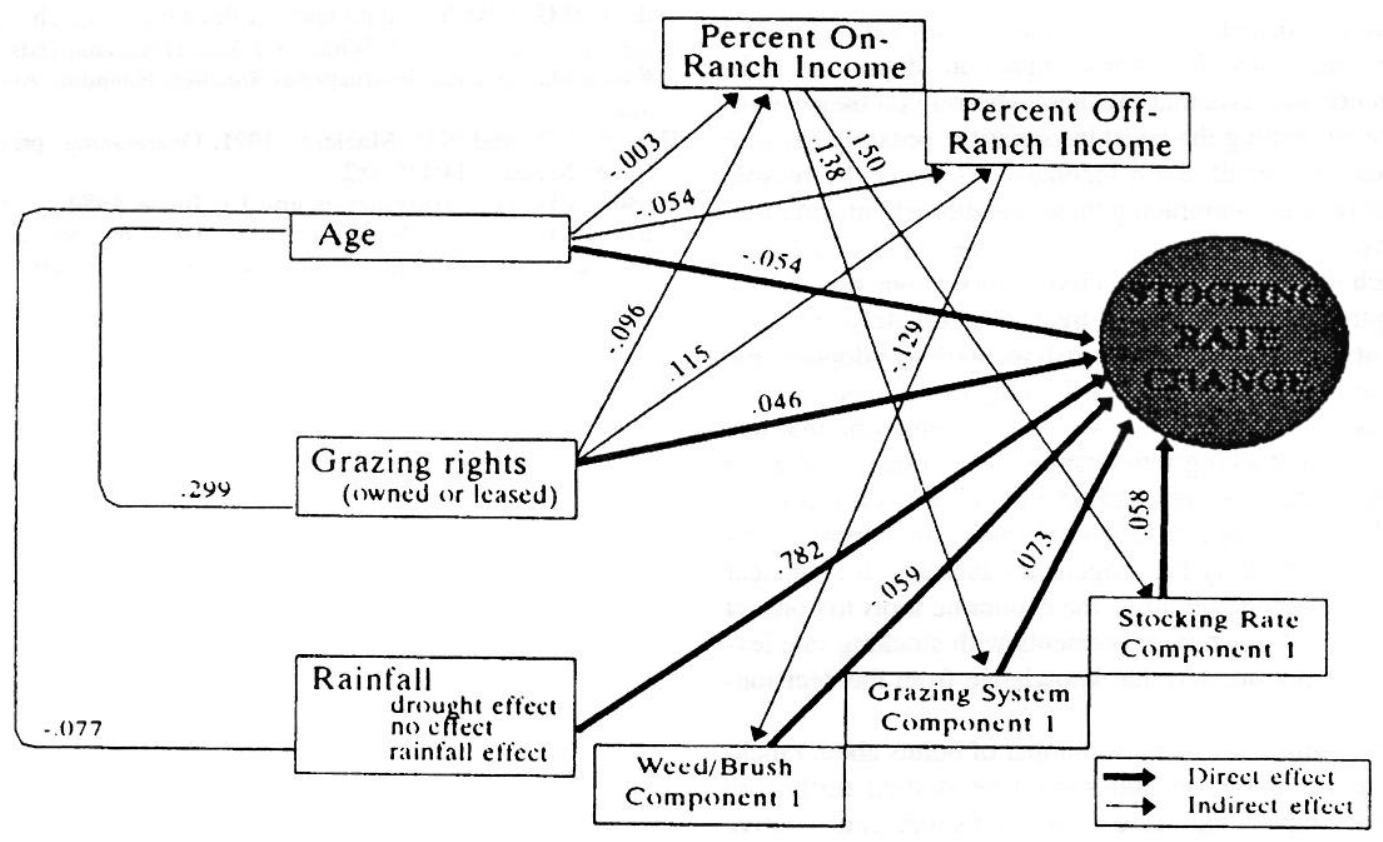

Fig. 2. Final model of significant direct and indirect effects of age, grazing rights, rainfall characteristics, traditional stocking rate factors, traditional grazing program factors and weed/brush information factors on stocking rate change. 
clude some provision for seasonal adjustment and limitation of livestock numbers should be encouraged. Long-term leases that encourage range improvement would benefit the current lessee as well as the landowner.

Stocking rate, by its very nature, should be a planning tool to achieve some goal for the future (e.g., maximize animal production/unit area, optimize profit/unit area, or increase condition and trend of the grazing land). As defined for this study, traditional stocking decisions include biotic (plants and animals) and abiotic factors (weather and experience). Ranchers are able to identify the stocking rate change (derived by squaring the standardized path coefficient). Other factors that explain stocking rate decision-making (other than traditional factors) may need to be explored to see their impact on stocking rate change over time.

The traditional grazing program factors had the largest impact of the decision variables on stocking rate change. Grazing programs are generally designed to improve the health and vigor of plant populations (Hanselka et al. 1988). When that goal is achieved, benefits may be increased production per unit area (Heitschmidt and Taylor 1991). Grazing programs can increase individual animal performance if the quality of forage presented to the animals is high. Rangeland operators indicated they considered improved livestock performance as the most important benefit from initiating a grazing program. Combined with a positive path coefficient linking the grazing component to stocking rate change, this would imply that ranchers expect to benefit from increased stocking rate levels and animal performance simultaneously. This scenario would be expected only if previous stocking levels were below the critical stocking rate (Heitschmidt and Taylor 1991). This obscure picture which ranchers have about the effects of grazing programs distorts efforts to improve range condition and trend.

Two components explained the variability in choices of treatment techniques for weed/brush control. The first was an informationsources component where ranchers put advice from neighbors and fear of treatment method at the top of the list. Thomas et al. (1990) reported that farmers with small gross farm sales were the ones to value their neighbors advice as the most important source of information. They showed that group meetings and contacts with extension and university professionals made the biggest impact on adoption of technology. This evidence suggests that ranchers who rely on their neighbors for advice are not getting the latest information, possibly because they too have relatively small ranch incomes. Whatever the reason, the outcome is that ranchers embracing these weed/brush informationsources had decreased stocking levels over time. One conclusion might be that ranchers who adopt a reactive stance about weed/brush treatment techniques defer decisions to treat, or alternately, information sources they utilize frustrate weed/brush technology adoption and eventually result in a reactive decline in stocking rate levels.

The second weed/brush component was an economic one that had no significant effect on stocking rate change. Thus, ranchers did not attribute much importance to costs and benefits of weed/brush treatment in altering their stocking rate levels. Herein is an extremely important educational opportunity for rangeland educators. It is unclear from this study if ranchers do not have the economic tools to connect short- or long-term weed/brush improvements with stocking rate levels or if they have simply omitted that knowledge from the decisionmaking process.

One implication of this study is that a number of points about rancher decision-making are indistinct and should be studied further by change agents. An attempt to segregate proactive factors from reactive is indicated in future research projects so their respective effects on resources can be measured. If we are to successfully shift the burden for cause and effect of decision-making to ranchers themselves, we must have better information about factors precipitating those decisions.

\section{Literature Cited}

Bowers, J.H., R.M. Sonoda, and D.J. Mitchell. 1990. Path coefficient analysis of the effect of rainfall variables on the epidemiology of Phytophthora blight of pepper caused by Phytophthora capsici. Phytopathology 80:14391446.

Hanselka, C.W., B.J. Ragsdale, and B. Rector. 1988. Grazing systems for profitable ranching. Texas Agric. Ext. Serv. L-2211. Texas A\&M Univ., College Station.

Hanselka, C.W., A. McGinty, B.S. Rector, R.C. Rowan, and L.D. White. 1990. Grazing and brush management on Texas rangelands: an analysis of management decisions. Texas Agric. Ext. Serv. Texas A\&M Univ., College Station.

Harrington, G.N., A.D. Wilson, and M.D. Young. 1984. Management of rangeland ecosystems, p. 3-12. In: G.N. Harrington, A.D. Wilson, and M.D. Young. Management of Australia's rangelands. CSIRO, Australia.

Heitschmidt, R.K. and C.A. Taylor. 1991. Livestock production, p. 161-177. In: R.K. Heitschmidt and J.W. Stuth (eds.). Grazing management: an eco- . logical perspective. Timber Press, Inc., Portland, Ore.

Kang, M.S., M.S. Zuber, and G.F. Krause. 1983. Path coefficient analyses of grain yield and harvest grain moisture in maize. Trop. Agric. (Trinidad) 60:253-256.

Kennedy, P. 1989. A guide to econometrics. The MIT Press, Cambridge, Mass.

Ladewig, H.W. 1977. Community satisfaction and public policy: theory and measurement. Ph.D. Diss. North Carolina State University, Raleigh.

Li, C.C. 1975. Path analysis: a primer. The Boxwood Press, Pacific Grove, Calif.

Mebrahtu, T., W. Mershie, and M. Rangappa. 1991. Path coefficient analysis of ozone effects on seed yield and seed yield components of bean (Phaseolus vulgaris L.). J. Hort. Sci. 66:59-66.

Rowan, R.C. and L.D. White. 1994. Regional differences among Texas rangeland operators. J. Range Manage. 47:338-343.

Rowan, R.C., H.W. Ladewig, and L.D. White. 1994. Perceptions vs. recommendations: a rangeland decision-making dilemma. J. Range Manage. 49:344-348.

Singh, B.P. and R.K. Chowdhury. 1983. Correlation and path coefficient analysis of seed yield and oil content in mustard (Brassica juncea). Can. J. Genet. Cytol. 25:312-317.

Thomas, J.K., H. Ladewig, and W.A. McIntosh. 1990. The adoption of integrated pest management practices among Texas cotton growers. Rural Sociology 55(3):395-410.

White, L.D. 1968. Factors affecting susceptibility of creosotebush (Larrea tridentata (D.C.) Cov.) to burning. Ph.D. Diss. Univ. of Arizona, Tucson.

Wilcox, D.G. 1982. The importance of flexibility in ranch management strategies, p. 15-26. In: L.D. White and A.L. Hoermann (eds.). Proc. Effective Ranch Management, International Ranchers Roundup. Aug., 1982, Del Rio, Tex.

Wilson, A.D. and N.D. Macleod. 1991. Overgrazing: present or absent? J. Range Manage. 44:475-482.

Wilson, A.D., G.N. Harrington, and I.F. Beale. 1984. Grazing management, p, 129-139. In: G.N. Harrington, A.D. Wilson, and M.D. Young. Management of Australia's rangeland. CSIRO, Australia. 